\title{
The Caligraphy of Balinese Script as A Form of Bali Creative Industry Based on Balinese Script
}

\author{
I Wayan Simpen ${ }^{1}$, I Nyoman Udayana ${ }^{2}$, Ida Bagus Rai Putra ${ }^{3}$ \\ ${ }^{1}$ Indonesian Literature \\ ${ }^{2}$ English Literature \\ ${ }^{3}$ Balinese Literature \\ Faculty of Arts, Udayana University \\ Denpasar, Bali \\ wyn_simpen@unud.ac.id
}

\begin{abstract}
Based on the language mapping conducted by The Language Development and Fostering Agency, there are around 560 regional languages in Indonesia. Of all these languages, only 11 regional languages have their own literacy system. One local language that has a literacy system is Balinese. Balinese script has a vital function in the effort of documenting and transmitting various systems of knowledge found by Balinese people from the past to the present. Besides having as documentation media, Balinese script is also functional in the three important stages of Balinese people's life. From the first stage (being born), the Balinese people used the script as a provision for the burial of the placenta. During adulthood, Balinese script is also used in a toothcutting rite. Similarly, when the Balinese people died, Balinese script was used as rajah-rajah kajang. There are contradictions that seem to be the gap between the functionalities of Balinese script and the reality of the low knowledge of Balinese people about Balinese script. It is an indisputable fact that Latin letters dominate various spheres of life. Realizing this, it needs the effort to make people realize the potential of Balinese script in the creative process of Balinese Script Calligraphy, which is important to be studied further. Balinese script that has a rounded shape (ngawindu) is very aesthetic to be developed into aesthetic forms of a variety. Not only that, from the searches carried out in some lontar storage sites in Bali, Balinese script calligraphy contains the use of interesting language and important literary values as a medium of educational media.
\end{abstract}

Keywords: Caligraphy, Balinese script, creative industry

\section{INTRODUCTION}

The existence of Balinese characters inherited by Balinese people in the context of the Bali problem is very important. Balinese script is not only for written language, but also has a very important function in maintaining, fostering, orchestrating, and developing Balinese culture. Bagus explained that Balinese characters have very close freedom with Balinese society, religion, and society (1980: 5). In religious life in Bali, Balinese scripts are almost applicable in every part of the religious activity.

The potential of Balinese calligraphy in the creative industry is caused by two factors, both internal and external. The internal factors referred to things related to the form, type, and spelling system in Balinese script. Meanwhile, external factors are related to the potential of Bali as a regional tourism destination. Judging from its shape, Balinese script has a more rounded character compared to Javanese script. The character of Balinese characters that are more rounded in Balinese is termed ngawindhu 'round like a circle ', mamatan titiran 'round like a titiran bird eyes', majit tuma 'round like tuma bottom shape', ngetumbah 'round like ketumbarkind of local spices', and majit payuk 'round like the bottom of a pot'. This round character can be used by an artist in his creative process to create various aesthetic visual forms.

Balinese script spelling system or pasang aksara Bali provides an opportunity to write any language using Balinese script. Other local languages, Indonesian, and foreign languages can be written using Balinese script, provided the writing 
follows the pronunciation of Balinese people. These internal factors are supported by external factors related to Bali's potential as a world tourism destination. With a good marketing system, this Balinese calligraphy is very likely to compete in Bali's tourism industry. Balinese calligraphy can be a breakthrough in the Balinese art world that can integrate literary art with fine arts. Not only that, but this can also preserve and develop the Balinese script, language, and literature.

From the explanation above, there are two problems that are the main focus of this paper. These problems are formulated in the form of questions as follows.

1. What is the existence of Balinese calligraphy in Bali nowadays?

2. What are the types of characters used in the creative process of creating Balinese calligraphy?

Theoretically, this research can be utilized in the development of studies on Balinese script. The study of Balinese calligraphy as a Balinese-based creative industry is important, to know more about the existence and types of characters used in Balinese calligraphy. Meanwhile, practically, a comprehensive knowledge of the existence and types of characters constructing Balinese calligraphy can be used to motivate Balinese to create more Balinese calligraphy. The potential of Balinese script, language, and literature in Balinese calligraphy is believed to have its own competitiveness in the world of creative industries. With the increasing number of citizens who are creative with Balinese script, there will be another expanding in the use of Balinese script in various spheres of life.

\section{RESEARCH METHOD}

The method applied in the study of Balinese Calligraphy as a Balinese Script-Based on Creative Industry follows three stages consisting of (1) data collection, (2) data analysis, and (3) analysis results presentation. In the data supply phase, two methods are used, observation and interview. After the data is collected, the next stage is data analysis. The data analysis stage is based on the theory of phonological and semiotic. The phonological theory is applied to analyze the types of Balinese script used in the creative process of creating Balinese calligraphy, while the semiotic theory is used to interpret the meaning of elements of Balinese language and literature contained in Bali Calligraphy. By applying these two theories, the whole problem can be solved.

In the stage of presenting the results of the data analysis, the method used is informal and formal methods. The informal method is the presentation of the results of analysis using ordinary words, including technical terminology. Meanwhile, the formal method is the presentation of the results of the analysis formulated with signs and symbols (Sudaryanto, 1993: 145; Mahsun, 2005: 224).

\section{RESULTS AND DISCUSSIONS}

a. The existence of Balinese script calligraphy

Balinese script inherited by Balinese people is not only used to write Balinese language and various things related to religious rituals. With its creativity, Balinese script is developed into a variety of aesthetically valuable forms or better known as Balinese script calligraphy/ Baligraphy. Balinese script calligraphy is a relatively new phenomenon in the creativity of developing the art of writing beautifully using Balinese script, although the art of beautiful writing with Balinese script has been firmly rooted in the history of the development of Balinese tradition.

The development of calligraphy in Indonesia that utilizes the potential of regional scripts that they have can be said to be not yet optimal enough. Among the 11 regional languages that have a literacy system in Indonesia, such as Javanese, Sundanese, Bugis (Makassar), Karo, Mandailing, Toba, Rejang, Kerinci, Lampung, Malay, and Balinese, only two characters that stretch their potential in developing calligraphy. The two characters referred to Javanese script and Balinese script. Javanese script literacy is well developed. It has even penetrated the creative industry sector. It is clearly an advanced business error in the defense and development of Javanese script.

Especially judging by the awareness of Balinese people who deliberately write Balinese script calligraphy, the phenomenon of Balinese script calligraphy is relatively new. However, if you look at the use of various forms of the script in the lives of beautiful Balinese people with non-literary variations, then the roots of calligraphy writing it seems quite old in Bali. Through his writing entitled Calligraphy in Balinese Culture, Suastika (2003: 130) includes various types of the tattoo as a form of calligraphy in Balinese script. If the identification done by Suastika is correct, then Balinese script calligraphy can be said to have existed since the time of Bali Kuna (around the $9^{\text {th }}$ century).

The term Baligrafi was purposed by Darma Putra in a meeting with some Balinese cultural figures and activists at the Gunarsa Museum in 2013. Nyoman Gunarsa as the owner of the museum is said to want to include calligraphy into the Balinese Language Festival in the form of a painting exhibition. Bali into the festival is considered Darma Putra very suitable because it is one form of glorifying Balinese characters into the world of painting and then everyday life. Besides, according to Darma Putra also because Bali until now seems not to have the art of Balinese calligraphy which is clearly seen, even though the world of Balinese painting has been developing for a long time.

Starting from the competition, the desire of the people to be creative with Balinese characters is increasing. It can be proven from some places that 
also store Balinese script calligraphy. The three places that store Balinese script calligraphy are the Lontar Study Center of Udayana University, Denpasar City Cultural Office, and Indonesian Hindu University. The Center for the Study of Lontar University of Udayana kept some Balinese script calligraphy works. The work according to the staff of the Lontar Study Center was granted by students of the Bali Literature Study Program, Faculty of Arts, Udayana University under the guidance of Ida Wayan Oka Granoka Gong.

\section{b. Literacy Used in Balinese Script Calligraphy}

The elements of Balinese script used in Balinese script calligraphy are important to be identified more deeply because Balinese script is the main media in creating various creativities of Balinese script calligraphy art. From some Balinese script classifications that have been described above, the classification of Balinese script is based on its form and function which includes the letters wreastra, swalalita, wijaksara, and modre will be used as a perspective to review the various characters used in Balinese script calligraphy. The wreastra script used to write the Balinese language appears to be used in Balinese script calligraphy. Some examples of Balinese script calligraphy that use the type of wreastra can be seen below.

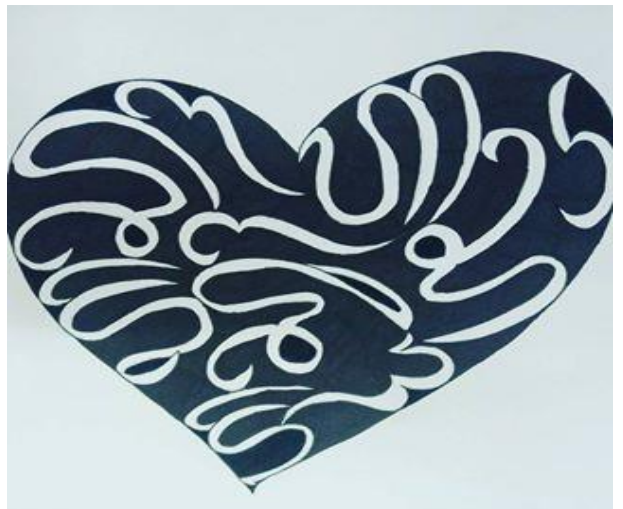

Balinese script calligraphy using Wreastra, Heart Shaped

The swalalita script used to write the Sanskrit absorption vocabulary, and Old Javanese in Balinese is used in Balinese script calligraphy. Some examples of Balinese script calligraphy that use the type of swalalita script can be seen below.

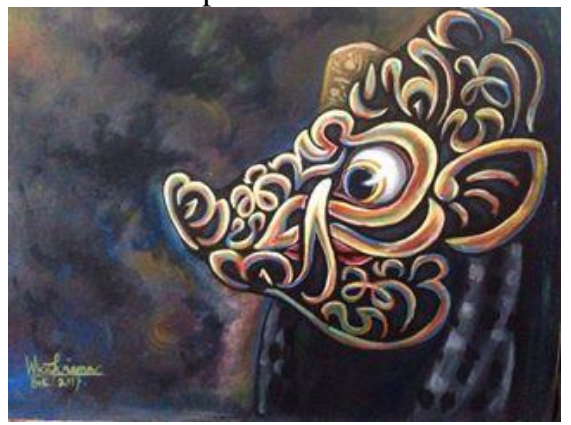

(Balinese script calligraphy uses Swalalita script in the form of Barong Kucit)
The wijaksara script is widely used in spells are also used in Balinese script calligraphy. The modre characters used for the sake of apparent religious rituals are also seen in Balinese script calligraphy. The use of wreastra and swalalita script allows Balinese script to be used in profane creative industrial designs. The creative industry in question is for example paintings for interior displays, Balinese souvenir clothes designs, bag designs, hats, and others. On the other hand, the use of wijaksara script and modre in some calligraphy allows Balinese script calligraphy to penetrate sacred or sacred places in Balinese society. By filling these two domains, Balinese script calligraphy can be a creative solution in the preservation and development of Balinese characters.

\section{CONCLUSION}

The description above shows that Balinese script calligraphy is very potential to be developed in the world of creative industries. Against the two main problems in this study, the conclusions produced can be described as follows.

1) The existence of Balinese script calligraphy that is developing at this time has strong roots in the dynamics of Balinese script history. During the Balinese period, Balinese script was not only used for writing inscriptions but also writing functional rajah kajang in the rites of the death of Balinese people. During the Middle Bali period, the literary works of Kidung Puspa Sancaya and Kidung Padma Muter were written on the padma flower petals, giving rise to an aesthetic impression that resembled the forms of Balinese script calligraphy today. In the days of Modern Bali, the emergence of Balinese script calligraphy was marked by the existence of the Bali Language Festival held at the Gunarsa Museum in 2013.

2) Balinese script calligraphy uses elements of Balinese script both classified in the ordinary script and sacred script. The fact shows that some artists use wreastra characters to write Balinese Kepara like the word asah, asih, asuh with heart patterns. Some artists also wrote using the swalalita script to write uptake vocabulary from Sanskrit or Old Javanese as the word śantih, santih, śantih with a barong-like pattern. Not only limited to ordinary characters, but some artists also use wijaksara characters which are commonly used in spells and ritual facilities. Wijaksara script which is used based on Balinese script calligraphy found in the discussion above, for example, sang, bang, tang, ang, and ang ah, the characters that are enthroned above the lotus flower. Balinese script calligraphy also comes to creations that use modre characters. It can be seen in some calligraphy works that make use of 
the rajah dasa bayu which reads i a ksa ma ra la wa ya ung.

\section{REFERENCES}

[1] Ananda Murti, Shrii Shrii. 2008. Tantra Jalan Pembebesan. India:Ananda Marga.

[2] Antara, I Gde Nala. 2008. 'Eksistensi Aksara Bali dalam Masyarakat Bali'. Denpasar: Jurusan Sastra Daerah Program dan Studi Doktor S3 Kajian Budaya.

[3] Arifin, Zainal dan Juniyah. 2009. Morfologi (Bentuk, Fungsi, dan Makna). Jakarta: PT. Gramedia Widiasarana Indonesia.

[4] Bagus, I Gusti Ngurah. 1980. Aksara dalam Kebudayaan Bali, suatu Kajian Antropologi(Pidato Pengukuhan Guru Besar). Denpasar: Universitas Udayana.

[5] Bandana, I Gde Wayan Soken, dkk. 2012. Bahasa, Aksara, dan Sastra Bali dalam Wacana Seremonial Kematian. Denpasar: Cakra Press.

[6] Bawa, I Wayan dan Jendra, I Wayan. 1981. Struktur Bahasa Bali. Denpasar: Pusat Pembinaan dan Pengembangan Bahasa.

[7] Chaer, Abdul. 2007. Kajian Bahasa Struktur Internal, Pemakaian, dan Pembelajaran. Jakarta: Pt.Rineka Cipta.

[8] ----------2007. Linguistik Umum. Jakarta: Rineka Cipta.

[9]-------------dan Agustian, Leonie. 2010. Sosiolinguistik Perkenalan Awal.Jakarta: Rineka Cipta.

[10] Duija, I Nengah. 2005. "Tradisi Kelisanan Menuju ke Keberaksaraan Refleksi "Masa Kegelapan" Kehidupan Manusia Bali". Denpasar: Jurusan Sastra Daerah dan Program Doktor (S3) Kajian Budaya, Fakultas Sastra, Universitas Udayana.

[11] Gelgel, I Ketoet. 1923. Tjontoh Menoelis Huruf Bali. Weltevreden: Landsdrukkerij.

[12] Ginarsa, Ketut. 1980. Sepintas tentang Sejarah Aksara Bali. Singaraja: Balai Penelitian Bahasa Cabang I.

[13] Gordon, Terrence. 1998. Saussure untuk Pemula. Yogyakarta: Kanisius

[14] Granoka, Ida Wayan. 1997. Perburuan ke Prana Jiwa Perburuan Seorang Ida Wayan Oka Granoka. Maha Bajra Sandi dan Universitas Udayana.

[15] ------------2007. Reinkarnasi Budaya. Denpasar: Maha Bajra Sandi dan Universitas Udayana.

[16] -----------2011. 'Epistemik Widya Cakra Universiter'. Denpasar: Maha Bajra Sandi (Makalah Disampaikan pada Stadium General Pengabdian Masyarakat Jurusan Sastra Bali)

[17] --------2011. 'Menorehkan Kembali Tinta Emas Peradaban Masa Depan Gemilang'. Denpasar: Maha Bajra Sandi. (Makalah
Disampaikan pada Seminar Nasional Arkeologi).

[18] Herusatoto, Budiono. Simbolisme dalam Budaya Jawa. Yogyakarta: PT. Hanindita.

[19] Hood, Beny H. 2008. Semiotika dan Dinamika Sosial Budaya.Depok : Fakultas Ilmu Pengetahuan Budaya (FIB) UI Depok.

[20] Jaman, I Gede.Rerajahan dalam Kehidupan. Surabaya: Paramita.

[21] Jendra, I Wayan.1976. Sebuah Ikhtisar Fonologi Bahasa Bali.Jurusan Sastra Jawa Kuna: Denpasar.

[22] -----------1981. Suatu Pengantar Ringkas Penyusunan Rancangan Penelitian. Denpasar : Fakultas Sastra Universitas Udayana.

[23] ------------1988. Pengantar Ringkas Ilmu Bahasa dan Perkembangannya. Surabaya: Paramita.

[24]-----------1976/1977. Morfologi Bahasa Bali: Denpasar: fakultas Sastra Universitas Udayana. 